The Construction of Professional Identity

\author{
Brianna Barker Caza \\ Asper School of Business \\ University of Manitoba \\ Winnipeg, MB R3T 5V4 \\ Canada \\ Phone: (204) 474-9482 \\ Email: brianna.caza@umanitoba.ca \\ Stephanie Creary \\ The School of Hotel Administration \\ Cornell University \\ Ithaca, NY 14853 \\ USA
}

Phone: (607) 255-8971

E-mail: sjc352@cornell.edu

Submitted Chapter for: Perspectives on Contemporary Professional Work Challenges and Experiences 


\section{The Construction of Professional Identity}

"I am a professional storyteller. My job is to engage with others, get pieces of their life stories, and feed it back to them in a way that gives them direction. I do this individually, at the seminar level, and through my blog."

(Tim, consultant, career manager, inspirational speaker)

\section{INTRODUCTION}

The classification of 'professions' has been a debated topic (Abbott, 1988; Friedson 2001), with several researchers putting forth varying criteria which distinguish a profession from other occupations. Previously, an individual would be considered a professional only once they had completed and attained all of the training, certifications and credentials of a professional occupation and, of course, internalized this profession's values and norms (Wilensky, 1964). Recently, researchers have begun to relax the criteria for classifying professional occupations, insisting only that the occupation be skill- or education-based (Benveniste, 1987; Ibarra, 1999). Furthermore, in today's workplace, which is burgeoning with independent knowledge workers, the term 'profession' is often used as an adjective rather than a noun, describing how individuals carry out their work with knowledge and skill rather than the specific kind of work they do (see Chapter 9 in this book).

Related to these changes has been the increasing complexity and plurality of professional work roles. Many professions are becoming multifaceted in nature, bridging several formerly distinct occupational roles (for example, nurse-midwife), and as such, the boundaries separating professions have blurred. Additionally, some professional workers are finding themselves drawn to multiple professions and refusing to settle for just one (for example, 'I am a lawyer and 
musician'). Highly educated, agentic knowledge workers often pursue multiple forms of work sequentially or simultaneously (Sliter \& Boyd, 2014). Hence, the broadening of the term 'profession' has enlarged the potential population of workers who have professional identities.

As the nature of the professions has changed, so too has professional identity construction. In the quote at the beginning of this chapter, Tim, a self-proclaimed professional storyteller, uses this label to explain how he goes about his work (with knowledge and skill). He describes many different professional roles which he considers to be functions of his profession as a storyteller. In doing so, he highlights one way in which individuals manage engagement in multiple professional roles through construction of a modem professional identity. In this chapter, we focus on understanding the construction and management of the modem pluralistic professional identity. The purpose of this chapter is to review, update and extend theory on professional identity to include the growing number of professionals who have multiple bases of identification, like Tim. To do this we first provide an overview of professional identity, explaining what it is, why it is important and how it has been studied. Then, we briefly review what has been said about professional identities that involve one single source of identification. In the next section we discuss professional identities that involve multiple sources of professional identification. Taking a subjective, interpretive view of identity, we propose that there are five main ways that individuals can structure their professional identity around multiple professional bases. Finally, we discuss the implications for the modern form of professional identification and suggest important directions for future research.

\section{PERSONAL IDENTITY}


A professional identity is an important cognitive mechanism that affects workers' attitudes, affect and behaviour in work settings and beyond. As such, understanding how professionals think about themselves has been the focus of many past research studies (e.g. Ashforth et al., 2007; Kreiner et al., 2006a; Kreiner et al., 2006b; Ibarra, 1999; Pratt et al., 2006).

Gecas (1982) defined identities as the various meanings that are attached to a person by themself and others. Importantly, identity is defined by one's subjective psychological experience, rather than some notion of objective reality of the 'true self' (Vignoles et al., 2006). Work identities, including but not limited to professional identities, are those meanings that individuals attach to themselves in the context of work (Dutton et al., 2010). Individuals draw from personal attributes, social group membership and work roles to assign meaning to who they are and what they do in the workplace (Ashforth et al., 2008). For the purposes of this chapter, we focus on professional identities as social and role-based work identities.

Individuals can construct their social or role-based work identities from aspects of their profession or their organization (Van Mannan and Barley, 1984). A professional identity is an individual's image of who they are as a professional (Slay and Smith, 2011); the constellation of attributes, beliefs, values, motives and experiences that people use to define themselves in their professional capacity (Schein, 1978). While organizational identities are indicators of where individuals work, professional identities indicate the type of work individuals do, and often signify which type of advanced training and skills one possesses (Pratt et al., 2006). This focus on doing (a role identity) is perhaps due to the fact that professional workers are seen as possessing certain specialized esoteric skills and knowledge (Lepisto et al., forthcoming), and are therefore unique from others in what they can 'do'. However, professional identities can also be seen as a social identity since identifying with a profession allows individuals entrance into a 
particular community comprised of individuals who share a common approach to a particular type of work (Van Maanen and Barley, 1984).

There are a few important assumptions underlying our conceptualization of professional identity. First, we view an individual's professional identity as a subjective construction that is influenced by the interpersonal interactions individuals have with others about their work. It is well accepted that individuals learn who they are as a professional by seeing themselves in the eyes of others (Cooley, 1902; Roberts et al., 2005). Through our interactions with others, we also learn about the role expectations of others, and may try to adapt or move away from these expectations. In this way, while we examine professional identity as an individual-level construct in this chapter, we acknowledge that it is formed and maintained through social interactions. Second, we assume that individuals have the potential to have multiple professional identities. For simplicity's sake, we talk about an individual's 'professional identity' and 'identity construction' in the next section. However, in subsequent sections we acknowledge that an individual may have more than one identity within the domain of work that can be at varying stages of construction and management. In fact, bringing the potential plurality of identities into the professional identity conversation is a major underlying goal of this chapter.

\section{Why Does Professional Identity Matter?}

An individual's professional identity as either a social or role identity is important because it is a key way that individuals assign meaning to themselves, and it shapes work attitudes, affect and behaviour (Siebert and Siebert, 2005). First, one's profession can be an important source of meaningfulness for individuals. In particular, the way in which an individual defines themself in their professional role becomes an important tool that the individual will use to understand and define themself and their life's purpose more generally. In fact, one's 
professional identity can serve as an organizing framework for an individual's self-concept (Hughes, 1958; Stryker, 1987). What this means is that the individual's professional identity is a focal point of their larger self-system. As Collin and Young (1992: 8) explained, in today's workplace, an individual's profession provides a 'context of meaning within which a life is lived and through which life is interpreted by others'. Through the construction of a professional identity, individuals are able to claim purpose and meaning for themselves, and explicate how they contribute to society.

In addition to being a meaning-making device, one's professional identity can also affect one's psychological well-being (Tajfel and Turner, 1979). Valued role identities have been theorized to protect individuals from depression and anxiety (Thoits, 1983). This is perhaps because individuals often evaluate their worth and competence through the lens of their identities (Cooley, 1902). Since the term 'professional' is positively used to describe someone with advanced training and unique knowledge and skills that allows them to provide an important service to society (Larson, 1977; Wallace, 1995), it is seen as a desirable self-description. It is therefore likely that when an individual identifies with a professional role, there will be psychological benefits. Valued role identities are linked to a sense of efficacy and esteem (Ervin and Stryker, 2001). As such, associating oneself with a respected profession can be an important source of well-being, esteem and pride. Professional occupations are seen to play important roles in society. Individuals who identify strongly with a valued profession are able to gain the benefits of a positive work identity (Dutton et al., 2010).

A professional identity also affects individual behaviour in the workplace. Professional norms and values impact upon job attitudes and shape behaviour (Bunderson, 2001). As a role identity, one's professional identity provides behavioural guidance in the workplace (Ibarra, 
1999). For instance, Leavitt et al. (2012) found that individuals' professional identities determined their moral decision-making and behaviour. In other workplace studies, professional identification has been shown to have positive performance outcomes such as career success (e.g. Arthur et al., 1989). Clearly, the important role of professional identity in shaping both psychological and behavioural processes in the workplace cannot be overstated.

\section{THE STATE OF PROFESSIONAL IDENTIFICATION AND THE PROCESS OF IDENTITY CONSTRUCTION}

There are two different approaches that scholars have taken in their examinations of professional identity. The first approach looks at identification as a state of being that explains how an individual views themself vis-ä-vis their profession; the professional identification scholars have investigated the antecedents that may predict the extent to which an individual may come to see their profession as self-defining, and the outcomes of doing so. The second approach focuses on understanding the content or meaning of a professional identity, and the process through which this meaning is constructed. Rather than looking at identification as a state, the identity construction literature affords individuals the agentic role of creating their own professional self-image. Insights into socialization practices and identity work both contribute to understanding professional identification and professional identity construction.

\section{Professional Identification}

To date, much of the research on professional identity (and other work-based identities) has focused on identification, or how individuals relate to the professional group with which they are associated (e.g. Elsbach, 1999; Pratt and Foreman, 2000). Professional identities, like all 
identities, can be considered self-cognitions that vary in their salience with respect to an individual's goals and core sense of self (Ashforth, 2001; Stryker, 1987). Professional identification is, thus, 'the extent to which one defines him or herself in terms of the work he or she does and the prototypical characteristics ascribed to individuals who do that work' (Mael and Ashforth, 1992: 106). Individuals who are highly identified with their profession will see their own beliefs about the profession as self-defining (Pratt, 1998), and will perceive 'oneness' with their professional group.

Professional identification has been described from both identity theory and social identity theory perspectives. Identity theory proposes that an individual's various identities (work and non-work) are arranged hierarchically according to their salience (Stryker and Burke, 2000). Thus, the strength of professional identification is the relative rank of one's professional selfdefinition in relation to the individual's other roles or social group memberships in the individual's self-hierarchy. Identity theorists propose that strong identification implies that the individual regards some particular social group or role to be a defining characteristic of who they are as an individual (Serpe and Stryker, 1987; Stryker, 1987). Social identity theory, which posits that people classify themselves and others into various social categories (Tajfel and Turner, 1985), complements this perspective by proposing that individuals are motivated towards identification with their professions because it reduces uncertainty and provides selfenhancement (Hogg and Terry, 2000). Identifying with a valued profession allows individuals to achieve and maintain positive images of themselves (Haslam, 2001). Both identity theorists and social identity theorists agree that when professional workers become identified with their profession, they will incorporate distinctive professional values and attitudes into their own selfidentity as a result of that membership, and will enact the role expectations of their profession. 
In general, strong identification has been associated with positive outcomes. The professionalism literature points out that internalized professional values become positively selfdefining for professional workers (e.g. Caplow, 1966; Morrow and Goetz, 1988). Further, Bergami and Bagozzi (2000) have conceptualized strength of identification as a form of 'cognitive commitment', which is a precursor to affective commitment. Thus, the more cognitively attached individuals are to their profession, the more affectively committed they will be. Identification is also positively related to individuals' self-esteem (Ashforth and Mael, 1989; Dutton et al., 1994). Additionally, high levels of professional identification are associated with more satisfied employees, and more extra-role supportive behaviours.

Because professional identification is often beneficial for individuals and their work organizations, researchers have been interested in uncovering its antecedents. Socialization, defined as the social learning process by which a person acquires specific knowledge and skills that are required in a professional role (Hall, 1987), plays an important role in shaping identification. Socialization is the key period within which individuals begin to form identification with their profession as they internalize the norms, values, behaviours and attitudes expected of their new roles. From a role identity perspective, socialization allows individuals to learn and practice the behavioural expectations of their new professional roles. From a social identity perspective, socialization provides a basis for attachment to one's new professional group, and reinforces this with social ties among group members.

From a professional identification perspective, scholars have found that professionals are often exposed to a long and intense socialization period into their occupational groups with the explicit goal of increasing their identification with the profession (e.g. Watts, 1987). In fact, some researchers have even theorized that the informal curriculum medical residents are exposed 
to during socialization may overpower some of the more technical 'official' curriculum (Becker et al., 1961). However, some professions may use more effective socialization tactics than others, making individuals within certain professions more apt to develop a strong professional identity than individuals in other professions (Van Maanen and Schein, 1979). Divestiture tactics, for example, are used to strip away any identities that individuals have upon entering the profession in order to make room for a new professional identity (Van Maanen and Schein, 1979). In addition, some professional identities are collectively less established, leading to a less developed base for individuals to identify with, culminating in weaker identification at the individual level (Hall, 1968). Further, researchers have found that the more selective a particular profession is in terms of entry into the field, the more likely it is that individuals will have a strong identification with the profession (Abbott, 1981; Hall, 1968).

In summary, much of the existing professional identification literature assumes that individuals vary in term of how important and salient their profession is to their overall selfconcept, and that quantifying this attachment in terms of its strength can help us to understand individual attitudes and behaviours at work. In large part, the research on professional identification suggests that socialization practices have a large effect on how strongly individuals identify with their profession. However, there are other antecedents that also influence identification, such as characteristics of the profession. Finally, professional identification is associated with several important organizational outcomes such as affective commitment and work satisfaction.

\section{Professional Identity Construction}

While the professional identification literature has focused on understanding when individuals form a perception of oneness with their profession, and the effect of this perception 
on affect and behaviour, the professional identity construction literature examines how individuals construct a subjective perception of themselves in their professional role. The identity construction research assumes that individuals are rarely passive recipients of the identification process, and as such socialization is not a unilateral process of conformity, but instead a negotiated adaptation of individuals to their professional environment (Schein, 1978; Nicholson, 1984; Ashford and Taylor, 1990). As such, this approach to understanding professional identity affords individuals a more agentic role in the identity formation process. In this respect, rather than investigating socializing agents' role in promoting an individual's identification with a target group, research on professional identity construction explains the specific cognitive and behavioural tactics that individuals engage in to form a professional identity.

Professional identity construction refers to a general process of identity formation and involves specific identity work, or 'interpretive activity involved in reproducing and transforming self-identity' (Alvesson and Willmott, 2002: 627). Scholars purport that individuals take an active role in professional identity construction by 'doing, acting, and interacting' in the social context (Pratt, 2012: 26). Drawing on role identity theory (e.g. Burke, 2006; Burke and Reitzes, 1981; Stryker, 1980; Stryker and Burke, 2000; Stryker and Serpe, 1994), research on professional identity construction emphasizes how cognitive and behavioural tactics change selfmeaning (e.g. Ibarra, 1999; Pratt et al., 2006). Ibarra (1999) revealed that workers learn to adapt to new roles by experimenting with 'provisional selves'. Provisional selves refer to 'temporary solutions people use to bridge the gap between their current capacities and self-conceptions and the representations they hold about what attitudes and behaviours are expected in the new role' (Ibarra, 1999: 765). Pratt et al. (2006) proposed cognitive tactics that are part of a larger process 
of identity construction. Specifically, they found that when medical residents experienced violations between what they did at work and their self-views, they engaged in enriching, patching or splinting tactics to construct their identities. Enriching occurred when the basic tenets of the physician identity remained the same, but the understandings of what it meant to be a physician deepened. Patching occurred when residents drew on one identity to reduce deficiencies in their understandings of other identities (for example, using identity as a medical generalist to improve understanding of identity as a surgeon). Splinting occurred when residents adopted a prior identity to strengthen a weak one (for example, viewing oneself as a medical student instead of as a radiologist).

Research on identity construction also provides some indication of the role that others in the organizational setting play in the identity construction process (e.g. Ibarra, 1999; Pratt et al, 2006), but this role tends to be portrayed as a more passive one. For example, socializing agents provide feedback and serve as role models who provide social validation (Ibarra, 1999; Pratt et al., 2006). Ibarra (1999) revealed that observing and obtaining feedback from more senior members influenced professionals' experimentation with 'provisional selves' and how they adapted to their new roles. Similarly, Pratt et al. (2006) proposed that 'validating via work feedback' and 'validating via role models' are important practices for self-assessment and identity construction.

In summary, research on professional identity construction assumes that individuals are active participants in the formation of their professional identity and that others in the social context play a more passive role. As such, individuals engage in cognitive and behaviour identity work in order to establish self-views that are more consistent with their image of what it means to be a member of a particular profession. This perspective offers an alternative and 
complementary view to the professional identification literature's focus on the role of professional and organizational agents in shaping an individual's perception of oneness with their profession. In the next section we turn to examining the professional identity construction process involving multiple professional roles, which characterizes much of professional work.

\section{ENGAGING IN MULTIPLE PROFESSIONAL ROLES}

While the current work on professions, professional identification, and professional identity construction has been informative about individuals who engage in and identify with a single profession, little has been said about individuals who take on multiple professional work roles. While doctors, lawyers and accountants in the 1950s may have pursued one professional role for life, today there are a growing number of individuals who are occupying multiple professional roles over the course of their careers. The idea of a single-profession career is growing to be an outdated concept. Many individuals experiment with multiple professions over the course of their careers. Some even engage in different professional roles simultaneously and, to some extent, find these roles to be interdependent. At the end of the twentieth century, it was reported that the number of women holding multiple jobs in Canada had tripled and was continuing to increase (Sussman, 1998). Four years later, it was reported that over 1.2 million UK citizens were holding multiple jobs (Simic and Sethi, 2002). In 2013, the Bureau of Labor statistics reported that over 7.2 million Americans were working in more than one job at a time. Clearly the idea of a single-profession career is becoming outdated. Many professional workers today are not just acquiring one set of specialized skills and knowledge, but instead are accumulating multiple sets of skills, and applying them in different ways. This growing segment of the working population has changed the professional identity construction process. In this 
section we examine these implications. First, we point out that an individual's participation in multiple professional roles may be externally driven (by the organization or profession), or selfinitiated. After reviewing each of these reasons for engaging in multiple professional roles, we discuss how individuals manage their professional identities around these multiple bases of identification through one of five possible identity structures.

\section{Externally Driven Multi-Professionalism}

Organizations and professions often put pressure on individuals to enact multiple professional roles. For instance, many organizations are creating dual or hybrid roles that are designed to help bridge professional boundaries and tasks within the organization. For instance, many healthcare organizations are now utilizing hybrid clinician managers (either nursemanagers or physician-managers) which require that individuals work in combined management and clinical roles in order to bridge clinical and economic interests (Braithwaite and Hindle, 2001; Ferlie and Shortell, 2001). By creating hybrid work roles within the hierarchy, organizations are able to expand the duties, responsibilities and expectations of their professional members. There are also profession-driven routes to multiple role-holding. At the profession level, there has been an increase in hybrid professions (or combinations of two other professions like nurses and midwives), particularly in the healthcare sector. These hybrid professions are introduced as the blending of two separate professions, but over time can evolve into having their own professional associations, meetings, protocols and training programmes.

\section{Self-Initiated Multi-Professionalism}


Engagement in multiple professional roles can also be voluntary. For instance, previous research has documented that a number of individuals find themselves transitioning from one profession to another at some point in their career (Ashforth, 2001; Ibarra, 1999, 2003). Some individuals do so voluntarily, choosing to leave one professional role that no longer feels like a good fit for their work needs. Other individuals may not necessarily want to leave a professional role, but may find that after they have retired, they still want to work, and to try something new. The media has termed this 'recareering' (Bracken, 2007). Still others may find that their work motivations extend beyond the bounds of a single profession and, thus, engage in multiple professional roles to fulfil those motivations. For instance, an individual may believe that he has both a creative side that feels fulfilled by writing a novel at night, and an intellectual side that has led him to pursue a $\mathrm{PhD}$ in contemporary English literature. This individual may choose to simultaneously engage in both of these professional roles.

\section{Managing Multiple Professional Identities}

Whether externally driven or self-initiated, engaging in multiple professional professions requires that individuals consider how to define themselves vis-ä-vis each professional role. All individuals possess multiple, and even conflicting, ways of conceptualizing themselves (Markus and Nurius, 1986; Stryer and Serpe, 1982; Tajfel and Turner, 1979), but differ in how they organize their multiple «professional group memberships intra-psychically. For example, when an individual enters into a new profession while continuing to participate in an old one, they may see both professions as self-defining, at least for a period of time. Consequently, by holding multiple roles, and finding both self-defining, the individual must then determine how these identities are subjectively represented in relation to one another within their self-concept. 
Questions regarding how identities are related to one another are inquiries about identity structure. Identity structure is often conceptualized on a continuum from simple or least complex to more complex (e.g. Linville, 1985; Roccas and Brewer, 2002). Linville $(1985,1987)$ defines self-complexity as the dimensionality underlying the self-concept. Building on Linville's work, Roccas and Brewer (2002) define social identity complexity as the degree to which individuals view their multiple identities as similar in terms of prototypic characteristics and/or overlapping in terms of in-group members. For instance, an individual who reduces multiple professional identities to a single, exclusive professional identity has a relatively simple professional identity structure. For example, a professor may define himself as a personality psychology researcher, identifying himself not just as an inhabitant of a general role (researcher) but as someone who researches a specific thing. In contrast, another professor with a slightly more complex identity may define herself as a researcher during the summer months, and a teacher during the academic term. Finally, a third professor may define herself as both as a teacher and a researcher, simultaneously. Rather than switching between these two role identities in different situations, she views herself as being both a teacher and a researcher across situations. As such, it is not the number of work roles an individual identifies with, but instead how individuals structure those identities in relation to one another, that determines identity complexity.

Herein, we discuss five professional identity structures for representing multiple professional identities that differ in their complexity. The first three these structures are adapted from Roccas and Brewer's (2002) discussion of social identity complexity. Our fourth structure is adapted from Ashforth and Johnson's (2001) conceptualization of 'holism'. We also contribute a fifth identity structure which enables us to broaden our scholarly understanding of identity complexity at work. To detail these structures, we first present three professional identity 
structures that range from least to slightly more complex: intersection, dominance and compartmentalization. Examples to support these identity structures are taken from data collected for a research project focused on certified nurse-midwives (CNMs). Then, we discuss two of the most complex identity structures, holistic and augmentation. Examples to support these identity structures are taken from data collected for a research project focused on certified yoga teachers. After presenting these cases separately, we discuss the similarities and differences among these five identity structures, and the benefits and drawbacks of increasing identity complexity.

\section{Less Complex Professional Identity Structures: Intersection, Dominance and}

\section{Compartmentalization}

Anna, Marcia and Susan are certified nurse-midwives (CNMs). A CNM is an individual who has undergone formal training in both nursing and midwifery. In the United States, they can be employed as independent practitioners, in hospitals or in small practices. As the name 'nursemidwifery' suggests, it is a 'hybrid profession' in that these individuals technically could claim membership in both professional groups, but the overlap of the groups has also now been formalized into its own profession (Ettinger, 2006). Moreover, CNMs practice aspects of typical nursing roles (for example, taking blood pressure, administering medicine), traditional midwifery roles (for example, being with women during labour), and roles that are unique to CNMs and not typical of neither nursing nor midwifery (for example, working autonomously but in a relationship with consulting physicians). Nurse-midwives have their own educational programmes, professional associations and practice guidelines. While all CNMs potentially have the same educational building blocks for their identities, there are differences in how individuals within the profession structure their professional identities. Specifically, we discuss three main 
ways that individuals working within this and other hybrid professions structure their identities. Anna views her professional identity as a 'certified nurse-midwife' as being at the intersection of the nursing identity and the midwife identity (intersection). Marcia defines her professional identity as a 'midwife', allowing this identity to dominate her nursing identity (dominance). Finally, Susan talks about herself as being both a midwife and a nurse, but at different points in time (compartmentalization). Below, we use data from interviews with Anna, Marcia, and Susan to elaborate on these three identity structures.

\section{Intersection}

Anna is a 35-year-old CNM working in a large teaching hospital. She explains that her profession is not 'nursing', nor does she define herself as a 'midwife'. She explains, 'A CNM is really an entirely different profession from nursing or general midwifery. I am really divorced from a lot of the medical training that makes nurses, but at the same time, I don't have the mindset of a radical midwife either. Luckily there are a growing number of us that are what I like to think of as "in-betweens".' Anna talks about the importance of her local CNM association and the larger national and international CNM associations in helping her to make professional choices, and to provide her with support. Anna said, 'When I have had a bad birth, I often will send a text out to my group of local CNMs because they get it. They may not be in my hospital, in fact most work at different hospitals all over the city, but they are the only ones who seem to share the same frame of mind as me.' As demonstrated by this statement, Anna does not strongly identify with the larger social identities of midwifery or nursing, but instead her reference group is the subset of individuals who are both nurses and midwives. These individuals have undertaken specialized Masters graduate work in nurse- midwifery, and follow the ACNM policy procedures and guidelines. Anna reiterates at the end of her interview, $\mathrm{T}$ am not a nurse 
and I am not a midwife. I am a certified nurse-midwife. We are this in between the medical and natural model, and have our own practice guidelines.' In this statement, Anna is showing that she identifies with an exclusive subgroup in her profession. Further, Anna discusses that many of her practices are unique to $\mathrm{CNM}$ training, and are not learned either in traditional midwifery school or through typical nursing programmes.

\section{Dominance}

Marcia is a 54-year-old CNM. Like Anna, she also works in a large hospital. However, Marcia structures her work identity differently than Anna. Marcia identifies as a midwife. She explains, $\mathrm{T}$ am a midwife first and foremost. I am technically a nurse-midwife, but to me the nursing part is really just so I could have more options of where I could practice. In many states lay midwives are not legally allowed to practice.' Marcia explains that she is inspired by all of the great midwives who changed the face of maternity care in the United States. When she discusses her profession, she talks about 'midwifery', not 'nurse-midwifery'. Being a midwife takes priority over and above the other work identities that she has. Marcia does not identify as a nurse in general, only as a nurse- midwife. Similarly, she also talks about herself as a hospital midwife, and an 'old school midwife'. But the label 'midwife' is consistently a part of all of her identity statements. Marcia sees midwives in general as her in-group, regardless of what type of midwife they are. However, she does not identify with nurses in general. In this way, her midwife professional identity dominates the nurse professional identity.

\section{Compartmentalization}

Susan is a 43-year-old CNM. She practices in a medium-sized metropolitan hospital. Susan talks about switching between her dual identities as a nurse and a midwife. She describes: 
There are some times in my job where I know I need to be the midwife, 'with woman'. This is the psychological part of my job, where I need to be her coach, to listen to her fears, to make it her experience. There are other times where I know I need to be her nurse. I need to take her blood pressure, give her care instructions, and help her to get through the birth. As a nurse-midwife, I am able to do whichever one the time calls for.

Susan's description demonstrates that she is compartmentalizing the multiple professional identities that she holds. While she sees herself as both a nurse and a midwife, unlike Marcia, she talks about enacting only one role at a time. She describes herself as a nurse when she is performing certain care tasks and a midwife when she is performing others. In this way, she identifies with each professional reference group equally, but separately.

Of these three CNMs, Susan has the more complex professional identity because she sees both her nursing and midwifery professional identities as important, valuable and self-referential, but only chooses to enact one at a time. On the other hand, both Anna and Marcia have more simplistic identity structures, choosing to identify with either a subset of the two identities, or just one identity. In the next section we move on to examining more complex professional identity structures wherein individuals structure their identities around multiple identity components simultaneously.

\section{More Complex Professional Identity Structures: Holism and Augmentation (Co-Activation)}

Kelly and Mary are certified yoga teachers. Yoga teacher certification is an emerging and increasingly popular professional practice around the world. Unlike many fitness specializations, becoming a yoga teacher requires completion of rigorous training and accredited credential programmes. Historically, and in the Eastern tradition, a guru or spiritual teacher (nearly always 
male) teaches his interested 'disciples' the practice of yoga (that is, asana) learned from ancient Hindu texts. A guru is not a self-appointed role. In order to become a guru, one must receive a consecration (that is, initiation rite) from one's own guru which is based solely on whether one's guru thinks his disciple is capable of initiating and instructing others in the practice of yoga (Wallis, 2012).

While a guru-disciple method of instruction continues in some yoga traditions, other traditions, particularly those in the Western world, are adopting a more professionalized approach to training individuals as yoga instructors. In the United States, Yoga Alliance is the largest non-profit association that registers yoga schools and yoga teachers. Most registered yoga schools (also known as 'yoga teacher training programmes') certify individuals as yoga teachers after completing 200 hours of education, which typically incorporates philosophy, anatomy, asana and meditation practice, and instruction and practice in the teaching of yoga to different populations. After receiving this initial certification, yoga instructors can register as a yoga teacher with Yoga Alliance. Registered yoga teachers must maintain professional standards (that is, pay professional dues and participate in continuing education programmes annually) in order to maintain their status as registered yoga teachers. Many settings that offer yoga instruction, including private yoga studios, gyms and fitness centres, require that yoga teachers hold one or more yoga teacher certifications and be registered with Yoga Alliance in order to gain and maintain their employment.

Like CNMs, our data from yoga instructors suggest that there is variety in how these professionals structure their professional identities. Below, we use data from interviews with Kelly and Mary to elaborate on the holism and augmentation professional identity structures.

\section{Holism}


Kelly is a 40-year-old life coach. She views her professional identity as a life coach as being a holistic identity that encompasses multiple professional identities as a "motivational coach', 'healer' and 'certified/registered yoga teacher'. As such, she also identifies with other motivational coaches, healers and certified yoga teachers who may or may not identify with other professions as well. Kelly also works in multiple settings. She sees private coaching clients at an alternative and holistic health centre that also offers various nutritional support, stress management and yoga programmes to the public. She also offers coaching and yoga classes in her home and in public outdoor spaces (parks, beaches, and so on). She explains:

Before finding my professional calling as a life coach, I had many different jobs and businesses, always searching for the right profession. Being a business owner, I enjoyed the freedom of implementing my own strategies to achieve goals, but I was selling something that didn't incorporate all of my skills, abilities and enthusiasm I had for motivating and healing people. So, I studied Eastern and Western principles through university degrees and related certifications which allowed me to cultivate my own wellness programmes integrating, mind, body, and spirit methods to show others how to manifest the lives they want.

Kelly's description demonstrates that she recognizes and embraces multiple professional group memberships to create a complex professional identity that is the sum total of all of her professional identities. Thus, all of her professional identities are important to her and salient across situations.

\section{Augmentation}


Mary is a 51-year-old Lutheran pastor, spiritual retreat leader, and certified, registered yoga teacher, but people refer to her as 'Pastor Mary' wherever she goes. Mary describes herself as a 'teacher at heart'. She explains:

As a pastor, I teach theology and Bible study. I teach karate now. I am teaching yoga as part of an outreach programme at my church which isn't just for church people. My definition of a yoga teacher is just someone who helps people to develop a full spectrum practice in their life. For me, that includes the spiritual/mental/physical, body/mind/soul, the whole person. I think Christianity doesn't really tap into the physical part of life. It does deal with the mind aspect and the spiritual aspect.

Mary talks about teaching yoga during the spiritual retreats she leads: 'I wanted to practice myself daily at a women's retreat I was leading and so I invited the other women to join me. A few women did.' As such, Mary sees that her identity as a yoga instructor enriches her identity as a Lutheran pastor and spiritual retreat leader. In this way, her multiple professional identities are distinct yet complementary and frequently co-activated in the same situation.

As these cases demonstrate, both Kelly and Mary structure their professional identities in a relatively more complex manner than do Anna, Marcia and Susan. Of the former two, we highlight the augmentation identity structure (Mary) as being the most complex. Kelly describes a multifaceted holistic professional identity wherein her multiple different work roles all fit under the umbrella classification of 'life coach'. On the other hand, describing the augmentation identity structure, Mary talked about how she defines herself as both a Lutheran pastor and a yoga teacher, honoring each identity separately and simultaneously, not attempting to put a more holistic categorization around the two. Like Susan, Mary sees herself as being both and each of the two identities she is associated with, but unlike Mary she describes herself as being both all 
of the time rather than one at a time. Being simultaneously both a pastor and a yoga instructor across time and context demonstrates a voluntary, chronic co-activation of these two professional identities.

Table 13.1 summarizes the five identity professional identity structures we have introduced and described in this section. The identity structures are displayed in the order we introduced them in the text, from least to most complex: intersection (Anna), dominance (Marcia), compartmentalization (Susan), holism (Kelly) and augmentation (Mary).

\section{Enabling and Constraining Professional Identity Complexity}

There are individual and contextual factors that can enable or constrain the level of professional identity complexity that individuals engaged in multiple professional roles display in the workplace. While we believe that there is the potential for individuals to structure their professional identities in any of the five ways we have highlighted, we acknowledge that there are particular characteristics surrounding the engagement in multiple professional roles that will influence complexity. Specifically, we propose that the degree to which engagement in multiple roles is self-initiated, and how the organization develops and applies professional labels, will influence individuals' identity structures.

First, the degree to which the engagement in multiple roles is voluntary is likely to be positively associated with the level of professional identity complexity. Identity structures higher in complexity, such as holism or augmentation identity structures, are more likely to be selfinitiated. Earlier, we differentiated between externally driven multiple role-holding and selfinitiated multiple professional role-holding. We explained that whether these roles were externally driven or self-initiated, individuals were tasked with managing these multiple roles 
cognitively through the structuring of their professional identity. While we believe that there is the potential for individuals to structure their professional identities in any of the five ways we have highlighted, we acknowledge that initiating engagement in multiple roles makes it more likely that the individual will structure their identities in a complex manner. When individuals voluntarily add on another work role while at the same time choosing to stay engaged in a previous work role, they are acknowledging that they have two distinct, but important professional identities. While some individuals may choose to merge these professional identity roles together into a more holistic job title (for example, life coach, like Kelly), others may focus on the distinct contribution of each separately (for example, a yoga coach and pastor, like Mary). Importantly, voluntarily engaging in multiple roles provides individuals with a great deal of discretion about how they want to structure two (or more) important roles. 
Table 13.1 Summary of professional identity structures

\begin{tabular}{|c|c|c|c|c|c|}
\hline & Intersection & Dominance & $\begin{array}{l}\text { Compartmental- } \\
\text { ization }\end{array}$ & Holism & Augmentation \\
\hline Description & $\begin{array}{l}\text { Individuals } \\
\text { define } \\
\text { themselves } \\
\text { at the } \\
\text { intersection } \\
\text { of two } \\
\text { professional } \\
\text { identities }\end{array}$ & $\begin{array}{l}\text { Individuals } \\
\text { define } \\
\text { themselves } \\
\text { by one } \\
\text { primary } \\
\text { professional } \\
\text { identity to } \\
\text { which all } \\
\text { others are } \\
\text { subordinated }\end{array}$ & $\begin{array}{l}\text { Individuals } \\
\text { define } \\
\text { themselves in } \\
\text { more than one } \\
\text { professional } \\
\text { roles, but } \\
\text { identifies each } \\
\text { profession at } \\
\text { different points in } \\
\text { time } \\
\text { (identity } \\
\text { activation is } \\
\text { context- or } \\
\text { situation-specific) }\end{array}$ & $\begin{array}{l}\text { Individuals } \\
\text { defines } \\
\text { themselves } \\
\text { with one, } \\
\text { holistic } \\
\text { professional } \\
\text { identity that } \\
\text { encompasses } \\
\text { all other } \\
\text { professional } \\
\text { identities }\end{array}$ & $\begin{array}{l}\text { Individuals } \\
\text { define } \\
\text { themselves } \\
\text { with multiple } \\
\text { professional } \\
\text { identities that } \\
\text { are } \\
\text { coactivated, } \\
\text { and } \\
\text { complement, } \\
\text { extend and } \\
\text { enhance one } \\
\text { another }\end{array}$ \\
\hline $\begin{array}{l}\text { Level of } \\
\text { cognitive } \\
\text { complexity }\end{array}$ & Low(est) & Low & Medium & High & High(est) \\
\hline Coactivation & No & No & No & No & Yes \\
\hline Integration & Integrated & Distinct & $\begin{array}{l}\text { Distinct and } \\
\text { separate }\end{array}$ & Integrated & $\begin{array}{l}\text { Distinct and } \\
\text { comple- } \\
\text { mentary }\end{array}$ \\
\hline $\begin{array}{l}\text { Reference } \\
\text { group }\end{array}$ & $\begin{array}{l}\text { Individuals } \\
\text { in the } \\
\text { specific } \\
\text { subspecialty } \\
\text { (e.g., all } \\
\text { nurse- } \\
\text { midwives) }\end{array}$ & $\begin{array}{l}\text { Individuals } \\
\text { in the } \\
\text { profession } \\
\text { at the top } \\
\text { of the } \\
\text { hierarchy } \\
\text { (this is the } \\
\text { most } \\
\text { valued } \\
\text { identity) } \\
\text { (e.g.. } \\
\text { midwives) }\end{array}$ & $\begin{array}{l}\text { Individuals who } \\
\text { are in the identity } \\
\text { group that is } \\
\text { salient at the time } \\
\text { (e.g., identifies } \\
\text { with nurses when } \\
\text { taking blood } \\
\text { pressure, a } \\
\text { nursing task) }\end{array}$ & $\begin{array}{l}\text { Individuals } \\
\text { who occupy } \\
\text { the general } \\
\text { superordinate } \\
\text { category } \\
\text { (e.g., life } \\
\text { coach) as } \\
\text { well as } \\
\text { subcomponents } \\
\text { (e.g., yoga } \\
\text { instructor) }\end{array}$ & $\begin{array}{l}\text { Individuals } \\
\text { who occupy } \\
\text { any of the } \\
\text { roles the } \\
\text { individual } \\
\text { inhabits }\end{array}$ \\
\hline
\end{tabular}

While internally driven multiple professional role-taking may be more likely to be naturally more aligned with a more complex professional identity structure, individuals may also adopt a complex identity structure to manage externally driven multiple professional roles. There are certain contextual features that will make it more likely that complexity accompanies multiple role-holding. First, organizations can ensure that individuals in hybrid professional roles feel part of both professional communities, not just those at the specific intersection of their roles. Making sure that individuals define their 'in-group' memberships broadly across professions is important. Unfortunately, while many organizations and professions encourage 
engagement in multiple roles, they often do not provide individuals with resources by which they can structure their identities around simultaneous engagement in these multiple roles. For example, by providing professionals with hybrid role 'labels' and by formalizing these roles, many organizations and professions may unintentionally push individuals toward simplifying their identity structure. For instance, nurse-managers may find themselves often grouped with other nurse-managers during organizational retreats. Additionally, as the role of 'nurse-manager' becomes more formalized, professional association meetings and training opportunities may further saturate individuals' reference groups to being more narrowly focused on people who are also both nurses and managers. As such, a nurse-manager's in-group may become more and more narrowly defined, which may contribute to a more simplistic identity structure. We suggest that more inclusive approaches to defining professional 'in-groups' will help to prevent this unintentional simplification of professional identity for individuals in hybrid professional roles.

\section{PRACTICAL IMPLICATIONS OF PROFESSIONAL IDENTITY COMPLEXITY}

Previous research has highlighted some potential downsides to structuring one's professional identity in ways that require chronic co-activation of identities. For instance, Rothbard and Ramarajan (2009) point out the potential for experiencing opposition or tension with co-activated identities. Trying to balance the demands of seemingly competing role identities can be psychologically and physically draining for individuals (Greenhaus and Beutell, 1985). In order to avoid feeling potentially overwhelmed, many individuals often gravitate towards simplifying their professional identity structure either by focusing on the intersection of their professional roles, or by allowing one role to dominate their professional identity as Anna, 
Marcia and Susan described. Doing so also allows individuals a more simplistic way of presenting themselves to others, which can be beneficial in certain social situations.

However, even when individuals structure their multiple work roles in a relatively simplistic manner, there may still be instances in which, despite their best efforts to keep them separate, one's professional identities become co-activated. For example, take a situation in which Susan, who identifies as both a midwife and a nurse, but prefers to do so at different points in time, finds herself needing to interact with both her patient, who thinks of her as a midwife, and the hospital anesthesiologist, who asks her to perform a nursing duty. In this situation Susan has both identities co-activated, but her preferred identity structure is to have them separated. Because her identity preferences are not aligned with her current work demands, she may find herself overwhelmed and feeling conflicted. This hypothetical situation highlights the fact that the way individuals structure their professional identities may be functional for getting them by on a day-to-day basis, but may not be optimal when situations call for coactivation of their multiple professional identities.

In fact, there is a growing amount of research which highlights the potential for positive experiences to result from co-activation of identities in the workplace (Caza and Wilson, 2009; Creary et al., 2015; Rothbard and Ramarajan, 2009). Individuals with more complex professional identity structures, who are comfortable in both identities that they hold, and who have considered the intersection and distinction between these identities, are likely to be better prepared to deal with situational co-activation of their identities. We suggest that positive benefits accrue when individuals' professional identity structures allow them to feel comfortable with their multiple identities being co-activated, therefore making co-activation a positive experience. 
In particular we believe that augmentation is unique in that it allows individuals to take advantage of the benefits of identity differentiation. Each professional identity is associated with important psychological and social resources (Creary et al., 2015; Luyckx et al., 2010; Thoits, 1985). As such, the more role identities an individual holds, the greater the role accumulation, and therefore the more behavioural guidance, sense of meaning, social support and other resources an individual will have at their disposal (Marks, 1977; Sieber, 1974; Thoits, 1985). Further, a greater number of identities that are easily accessible not only allows the individual to accumulate resources from each separate identity, but also enables individuals to draw resources from any one of these professional identities at any time. Further, having multiple identities chronically co-activated allows individuals to fully explore the synergistic nature of these resources. For instance Mary is able to reflect on how her practice as a yoga teacher can complement and extend her ability to fulfil her calling as a pastor. In this way, the individual not only has a greater pool of resources to draw from, but also has the potential to extend and enhance these resources by combining them in new and unique ways (Caza and Bagozzi, 2015; Creary et al., 2015).

Given these benefits of professional identity complexity, especially in a work environment that has an increased demand for multiple professional role engagement, we believe it is in the best interests of the employee, the profession and the organization to encourage complexity and co-activation of professional identities. One way in which organizations can do so is by helping modern professionals to focus on identifying complementary professional areas and offering continuing education credits towards these courses. In doing so, individuals are able to take a more interdisciplinary perspective towards their own profession. Just as Mary talked about finding synergies between her yoga work and her pastor work, so individuals can find 
exposure to other professions enriching and perhaps advantageous for their original professional role. Complementary roles may not always be associated roles, such as nurse and midwife, but may instead be counterbalancing roles. For example take Lozzie, a state attorney who recently became a certified Pilates instructor. She explained that her motivation for teaching Pilates classes was not financial, nor was it intended to fill up her already overbooked schedule. Instead, she was motivated toward taking on another professional role (and professional identity) in order to balance out the demands of her cognitively stressful job with a physical one. Organizations may be able to help modem professionals find ways to counterbalance their own intense professions by finding complementary professions to pair them with.

Another way that organizations and professions can encourage complexity, and even coactivation, is to become more accepting of creative new role combinations, and encouraging individuals to bring 'their whole selves' into work (Creary et al., 2015). Doing so allows individuals to celebrate their diversity in interests, backgrounds and other identities, and allows these to be seen as relevant and important in the workplace. People will then be able to practice being both in the workplace, and not checking certain identities at the door to only inhabit one 'professional' cloak.

\section{SUMMARY AND CONCLUSION}

In this chapter, we reviewed the literature on identification and identity construction. We then extended the literature to focus on how individuals structure their professional identities around multiple professional roles. We discussed five different identity structures that professionals may utilize to manage their engagement in multiple professional roles. We ended 
by highlighting the benefits of identity complexity and discussing ways in which individuals and their social context can enable complexity in professional identity structure.

At the start of the chapter, we pointed out that while 'profession' used to be thought of only as a noun, it is now increasingly used as an adjective. The effect of this is that the concept of a 'profession' has become enlarged and accepting, and as such the notion of 'professional identity' has also become unrestricted. Individuals work in established professions, emerging professions, and sometimes both. The subjective nature of identity construction in combination with the increasing agentic nature of the modem workforce has allowed individuals to craft their own unique professional identities. Not only will we have moved away from a narrow focus on individuals in very specific occupations, but we will also move away from setting stifling behavioural expectations on individuals who take up particular roles. Instead, we will move towards understanding professional identity as being a unique construction of who one is when one is finding ways to contribute meaningfully to society.

Previously individuals were often in pursuit of the one, single, 'right' job; the professional identity that fitted who they were, and who they wanted to become. Workers were encouraged by the idea that once they found the right job, the one that fitted them, they would enjoy a sense of meaning, positive self-image and higher well-being (Dobrow, 2006; Torrey and Duffy, 2012; Wrzesniewski et al., 1997). But professions today are changing, and many workers are being asked to take on multiple work roles. Other workers are refusing to limit their sense of self and their work experiences to the confines of a single profession. Instead, many highly educated and agentic workers are engaging in multiple professions to increase the fulfillment of their work. The combination of these social and individual forces has required that we rethink the nature and purpose of the professional identity, putting a greater emphasis on identity structure 
rather than perceptions of oneness with a single, particular reference group. Further, the more complex the professional identity structure becomes, the more likely it is that the professional will be able to adapt to different work situations. 


\section{REFERENCES}

Abbott, A. (1981). Status and status strain in the professions. American Journal of Sociology, 86, 819-835.

Abbott, A. (1988). The System of Professions: An Essay on the Division of Expert Labor. Chicago, IL: University of Chicago Press.

Alvesson, M. and Willmott, H. (2002). Identity regulation as organizational control: Producing the appropriate individual. Journal of Management Studies, 39, 619-644.

Arthur, M.B., Hall, D.T. and Lawrence, B.S. (1989). Handbook of Career Theory. New York: Cambridge University Press.

Ashford, S.J. and Taylor, M.S. (1990). Adaptation to work transitions: An integrative approach. In G.R. Ferris and K.M. Rowland (eds), Research in Personnel and Human Resources Management, Vol. 8. Greenwich, CT: JAI Press, pp. 1- 39.

Ashforth, B.E. (2001). Role Transitions in Organizational Life: An Identity-Based Perspective. Mahwah, NJ: Lawrence Erlbaum Associates.

Ashforth, B.E., Harrison, S.H. and Corley, K.G. (2008). Identification in organizations: An examination of four fundamental questions. Journal of Management, 34: 325-374.

Ashforth, B.E. and Johnson, S.A. (2001). Which hat to wear? The relative salience of multiple identities in organizational contexts. In M.A. Hogg and D.J. Terry (eds), Social Identity Processes in Organizational Contexts. Philadelphia, PA: Psychology Press, pp. 31-18.

Ashforth, B.E., Kreiner, G.E., Clark, M.A. and Fugate, M. (2007). Normalizing dirty work: Managerial tactics for countering occupational taint. Academy of Management Journal, $50,149-174$.

Ashforth, B.E. and Mael, F. (1989). Social identity theory and the organization. Academy of Management Review, 14, 20-39. 
Benveniste, G. (1987). Professionalizing the Organization: Reducing Bureaucracy to Enhance Effectiveness. San Francisco, CA: Jossey-Bass.

Becker, H.S., Geer, B., Hughes, E.C. and Strauss, A.L. (1961). Boys in White: Student Culture in Medical School. Chicago, IL: University of Chicago Press.

Bergami, M. and Bagozzi, R.P. (2000). Self-categorization, affective commitment and group self-esteem as distinct aspects of social identity in the organization. British Journal of Social Psychology, 6, 17-55.

Bracken, D. (2007). Career of Gold: Defeat Age Bias by Re-Careering for the Second Half of Your Life. New York: History Publishing Company.

Braithwaite, J. and Hindle, D. (2001). Acute health sector reform: An analysis of the Australian Senate's proposals. Australian Health Review, 24(1), 3-9.

Bunderson, J.S. (2001). How work ideologies shape the psychological contracts of professional employees: Doctors' responses to perceived breach. Journal of Organizational Behavior, 22(7), 717-741.

Burke, P.J. (2006). Identity change. Social Psychology Quarterly, 69, 81-96.

Burke, P.J. and Reitzes, D.C. (1981). The link between identity and role performance. Social Psychology Quarterly, 44(2), 83-92.

Caplow, T. (1966). Sequential steps in professionalization. In H.L. Vollmer and D.L Mills (eds), Professionalism. Englewood Cliffs, NJ: Prentice-Hall, pp. 19- 21.

Caza, B.B. and Bagozzi, R. (2015). Working through adversity: The effect of professional identity on resilience and burnout at work. Working Paper.

Caza, B.B. and Wilson, M.G. (2009). Me, myself, and I: The benefits of work-identity complexity. In L.M. Roberts and J.E. Dutton (eds), Exploring Positive Identities and 
Organizations: Building a Theoretical and Research Foundation. New York: Routledge Taylor \& Francis Group, pp. 99-123.

Collin, A. and Young, R.A. (1992). Constructing career through narrative and context. In R.A. Young and A. Collin (eds), Interpreting Career: Hermeneutical Studies of Lives. Westport, CT: Praeger, pp. 1-14.

Cooley, C. (1902). Human Nature and the Social Order. New York: Scribners.

Creary, S.J., Caza, B.B. and Roberts, L.M. (2015). Out of the box? How managing a subordinate's multiple identities affects the quality of a manager- subordinate relationship. Academy of Management Review, 40(4): 538-562.

Dobrow, S. (2006). Having a calling: A longitudinal study of young musicians. Unpublished dissertation, Harvard University.

Dutton, J.E., Dukerich, J.M. and Harquail, C. (1994). Organizational images and member identification. Administrative Science Quarterly, 39, 239-263.

Dutton, J.E., Roberts, L.M. and Bednar, J.S. (2010). Pathways for positive identity construction at work: Four types of positive identity and the building of social resources. Academy of Management Review, 35, 265-293.

Elsbach, K. (1999). An expanded model of organizational identification. Research in Organizational Behavior, 21, 163-200.

Ervin, L.H. and Stryker, S. (2001). Theorizing the relationship between self-esteem and identity. In T.J. Owens and S. Stryker (eds), Extending Self-Esteem Theory and Research: Sociological and Psychological Currents. New York: Cambridge University Press, pp. 29-55. 
Ettinger, Laura E. (2006). Nurse-Midwifery: The Birth of a New American Profession. Columbus, OH: Ohio State University Press.

Ferlie, E.B. and S.M. Shortell (2001). Improving the quality of health care in the United Kingdom and the United States: A framework for change. Milbank Quarterly, 79(2): 281315.

Freidson, E. (2001). Professionalism: The Third Logic. Chicago, IL: University of Chicago Press.

Gecas, V. (1982). The self-concept. Annual Review of Sociology, 8, 1-33.

Greenhaus, J.H. and Beutell, N.J. (1985). Sources and conflict between work and family roles. Academy of Management Review, 10, 76-88.

Hall, D.T. (1987). Careers and socialization. Journal of Management, 13(2): 301-322.

Hall, R. (1968). Professionalization and bureaucratization. American Sociological Review, 33 (February), 92-104.

Haslam, S.A. (2001). Psychology in Organizations: The Social Identity Approach. London: Sage.

Hogg, M.A. and Terry, D.J. (2000). Social identity and self-categorization processes in organizational contexts. Academy of Management Review, 25, 121-140.

Hughes, E. (1958). Men and Their Work. New York: Free Press.

Ibarra, H. (1999). Provisional selves: Experimenting with image and identity in professional adaptation. Administrative Science Quarterly, 44(4): 764-791.

Ibarra, H. (2003). Working Identity: Unconventional Strategies for Reinventing your Career. Cambridge, MA: Harvard Business School Press. 
Kreiner, G.E., Ashforth, B.E. and Sluss, D.M. (2006a). Identity dynamics in occupational dirty work: Integrating social identity and system justification perspectives. Organization Science, 17, 619-636.

Kreiner, G.E., Hollensbe, E.C. and Sheep, M.L. (2006b). Where is the 'Me' among the 'We'? Identity work and the search for optimal balance. Academy of Management Journal, 49, 1031-1057.

Larson, M.S. (1977). The Rise of Professionalism. Berkeley, CA: University of California Press.

Leavitt, K., Reynolds, S.J., Barnes, C.M., Schilpzand, P. and Hannah, S.T. (2012). Different hats, different obligations, plural occupational identities, and situated moral judgment. Academy of Management Journal, 55(6), 1316-1333.

Lepisto, D.A., Crosina, E. and Pratt, M.G. (forthcoming). Identity work within and beyond the professions: Toward a theoretical integration and extension. In A. Desilva and M. Aparicio (eds), International Handbook about Professional Identities.

Linville, P.W. (1985), Self-complexity and affective extremity: Don't put all of your eggs in one cognitive basket. Social Cognition, 3, 94-120.

Linville, P.W. (1987). Self-complexity as a cognitive buffer against stress-related illness and depression. Journal of Personality and Social Psychology, 52, 663-676.

Luyckx, K., Duriez, B., Klimstra, T.A. and De Witte, H. (2010). Identity statuses in young adult employees: Prospective relations with work engagement and burnout. Journal of Vocational Behavior, 77, 339-349.

Mael, F. and Ashforth, B.E. (1992). Alumni and their alma mater: A partial test of the reformulated model of organizational identification. Journal of Organizational Behavior, $13,103-123$. 
Marks, S.R. (1977). Multiple roles and role strain: Some notes on human energy, time, and commitment. American Sociological Review, 42, 921-936.

Markus, H. and Nurius, P. (1986). Possible selves. American Psychologist, 41, 954-969.

Morrow, PC. and Goetz, J.F. (1988). Professionalism as a form of work commitment. Journal of Vocational Behavior, 32, 92-111.

Nicholson, N. (1984). A theory of work role transitions, Administrative Science Quarterly, 29(2), 172-191.

Pratt, M.G. (1998). To be or not to be: Central questions in organizational identification. In D.A. Whetton and PC. Godfrey (eds), Identity in Organizations: Building Theory Through Conversations. Thousand Oaks, CA: Sage Publications, pp. 171-207.

Pratt, M.G. (2012). Rethinking identity construction processes in organizations: Three questions to consider. In M. Schultz, S. Maguire, A. Langley and H. Tsoukas (eds), Perspectives on Process Organization Studies: Constructing Identity In and Around Organizations. London: Oxford University Press, pp. 21-49.

Pratt, M.G. and Foreman, P. (2000). Classifying managerial responses to multiple identities. Academy of Management Review, 25, 18-42.

Pratt, M.G., Rockmann, K.W. and Kaufmann, J.B. (2006). Constructing professional identity: The role of work and identity learning cycles in the customization of identity among medical residents. Academy of Management Journal, 49(2), 235-262.

Roberts, L.M., Dutton, J.E., Spreitzer, G.M., Heaphy, E.D. and Quinn, R.E. (2005). Composing the reflected best self portrait: Building pathways for becoming extraordinary in work organizations. Academy of Management Review, 30, 712-736. 
Roccas, S. and Brewer, M.B. (2002). Social identity complexity. Personality and Social Psychology Review, 6(2), 88-106.

Rothbard, N. and Ramarajan, L. (2009). Checking your identities at the door? Positive relationships between non-work and work identities. In Laura M. Roberts and Jane E. Dutton (eds), Exploring Positive Identities and Organizations: Building a Theoretical and Research Foundation. New York: Psychology Press, pp. 125-148.

Schein, E.H. (1978). Career Dynamics: Matching Individual and Organizational Needs. Reading, MA: Addison-Wesley.

Serpe, R.T. and Stryker, S. (1987). The construction of self and reconstruction of social relationships. In Edward Lawler and Barry Markovsky (eds), Advances in Group Processes. Greenwich, CT: JAI, pp. 41-66.

Sieber, S.D. (1974). Toward a theory of role accumulation. American Sociological Review, 39(4), 567-578.

Siebert, D.C. and Siebert, C.F. (2005). The caregiver role identity scale: A validation study. Research on Social Work Practice, 15, 204-212.

Simic, M. and Sethi, S. (2002). People with second jobs: Analysis of the trends and characteristics of people who do two jobs. Labour Market Trends, 110(5), 239-247.

Sliter, M. and Boyd, E.M. (2014). Two (or three) is not equal to one: Multiple jobholding as a neglected topic in organizational research. Journal of Organizational Behavior, 35(7), 1052-1056.

Slay, H. and Smith, D.A. (2011). Professional identity construction: Using narrative to understand the negotiation of professional and stigmatized cultural identities. Human Relations, 64, 85-107. 
Stryker, S. (1980). Symbolic Interactionism: A Social Structural Version. Menlo Park, CA: Benjamin Cummings.

Stryker, S. (1987). The Interplay of Affect and Identity: Exploring the Relationships of Social Structure, Social Interaction, Self, and Emotion. Chicago, IL: American Sociological Association.

Stryker, S. and Burke, P.J. (2000). The past, present, and future of an identity theory. Social Psychology Quarterly, 63, 284-297.

Stryker, S. and Serpe, R.T. (1982). Commitment, identity salience, and role behavior: A theory and research example. In W. Ickes and E.S. Knowles (eds), Personality, Roles, and Social Behavior. New York: Springer-Verlag, pp. 199-218.

Stryker, S. and Serpe, R.T. (1994). Identity salience and psychological centrality: Equivalent, overlapping, or complementary concepts? Social Psychology Quarterly, 57, 16-35.

Sussman, D. (1998). Moonlighting: A growing way of life. Perspectives on Labour and Income, Statistics Canada, Catalogue no. 75-001-XPE, 10(2), 24-31.

Tajfel, H. (1974). 'Social identity and intergroup behavior'. Social Science Information, 13(2), $65-93$.

Tajfel, H. and Turner, J.C. (1979). An integrative theory of intergroup conflict. In W.G. Austin and S. Worchel (eds), The Social Psychology of Intergroup Relations. Monterey, CA: Brooks/Cole, pp. 33-48.

Tajfel, H. and Turner, J.C. (1985). The social identity theory of intergroup behavior. In S. Worchel and W.G. Austin (eds), Psychology of Intergroup Relations. Chicago, IL: Nelson-Hall, pp. 7-24. 
Thoits, P. A. (1985). Social support and psychological well-being: Theoretical possibilities. In I.G. Sarason and B.R. Sarason (eds), Social Support: Theory, Research, and Applications. Boston, MA: Martinus Nijhoff, pp. 51-72.

Torrey, C.L. and Duffy, R.D. (2012). Calling and well-being among adults: Differential relations by employment status. Journal of Career Assessment, 20, 415-425.

Van Maanen, J. and Barley, S.R. (1984). Occupational communities: Culture and control in organizations. Research in Organizational Behavior, 6, 287-365.

Van Maanen, J. and Schein, E.H. (1979). Toward a theory of organizational socialization. Research in Organizational Behavior, 1, 209-264.

Vignoles, V.L., Regalia, C., Manzi, C., Golledge, J. and Scabini, E. (2006). Beyond self-esteem: Influence of multiple motives on identity construction. Journal of Personality and Social Psychology, 90, 308-333.

Wallace, J.E. (1995). Organizational and professional commitment in professional and nonprofessional organizations. Administrative Science Quarterly, 40, 228-255.

Wallis, C. (2012). Tantra Illuminated. Woodlands, TX: Anusara Press.

Watts, R. (1987). Development of professional identity in Black clinical psychology students. Professional Psychology: Research and Practice, 18, 28-35.

Wilensky, H. (1964). The professionalization of everyone? American Journal of Sociology, 70: $137-158$.

Wrzesniewski, A., McCauley, C., Rozin, R. and Schwartz, B. (1997). Jobs, careers, and callings: People's relations to their work. Journal of Research in Personality, 31, 21-33. 